\title{
Biotic Stress Related Challenges on Cashew Production in Andhra Pradesh, India
}

\author{
Sudeepta Pattanayak*, Siddhartha Das and Hari Keerthi \\ Department of Plant Pathology, MS Swaminathan School of Agriculture, Centurion \\ University of Technology and Management, Paralakhemundi, Odisha, India
}

*Corresponding author

\section{A B S T R A C T}

\begin{tabular}{|l|}
\hline Ke y w o r d s \\
Cashew, Biotic \\
stress, Production, \\
Challenges \\
\hline Article Info \\
\hline $\begin{array}{l}\text { Accepted: } \\
\text { 30 May } 2020 \\
\text { Available Online: } \\
\text { 10 June } 2020\end{array}$ \\
\hline
\end{tabular}

Cashew nut (Anacardium occidentale) is an important plantation crop and played a crucial role in Indian economy. This tropical nut and fruit are used under a variety of cooked foods, bakery industry and various other culinary purposes. Cashew is highly demanding and valuable in market for its outstanding test among all nuts. The true fruit of cashew is drupe type and nut grow at end of the cashew apple. In India, Maharashtra ranks first in cashew production followed by Andhra Pradesh and Odisha. In Andhra Pradesh, cashew nut cultivated mainly in 8 different districts of coastal region which occupies total 1.83 lakhs ha with a production of 99,000 Tonnes. Tough India has gained such an important position but every year cashew production faced biotic stress related drastic loss. Problems encircling cashew production are - proper land condition, getting skilled labour, sufficient funding or investment, Government loans, maximize exposure of products through marketing. Additionally, value added tax and turnover tax by the Government are considered to be the major problem. Various state Governments like Andhra Pradesh, giving 50\% subsidy to farmers to encourage in cashew production and to fight against major biotic stresses like pestalotia leaf spot (Pestalotia heterocornis), anthracnose (Colletotrichum gloeosporides), gummosis (Lasiodiplodia theobromine), bacterial leaf spot (Xanthomonas citri pv. anacardii), the major pest such as tea mosquito bug, leaf folder, leaf Webber, stem and root borer leaf minor etc. The present article is a comprehensive draft on major biotic stress related challenges on cashew production in India.

\section{Introduction}

Fruit production in horticulture sector, is gaining more importance in Indian economy due to employment generation and source of income in rural areas. In horticulture crops, plantation crops like cashew nut are high valued product. The crop is mainly grown in waste lands in high rainfall regions. Hence it is called 'gold mine' of waste lands as it requires low inputs for production in early days it is the only crop for a forestation and soil conservation now it became the dollar earning crop plantation crop in India. Cashew nut (Anacardium occidentale) (familyAnacardiaceae) is a native to Brazil and is introduced in India in early 1550's.

Cashew is perennial crop and produce accessory or pseudocarp type of fruit. Cashew growing areas in Andhra Pradesh are Srikakulam, Vizianagaram, Vishakapatnam and up land areas of east and west Godavari districts, Krishna, Guntur, Prakasham, 
Nellore, coastal zone of Chittoor and Rayalaseema districts and area/production covered approximately 1.83 lakhs ha/1 lakh tone. In Andhra Pradesh mostly growing varieties are BPP 4, BPP 6, BPP 8 and in Orissa Bhubaneswar 1, BPP 8 and Dhana. This can be grown in soils having high organic matter such as forest soil, high water retention capacity like sandy loam soils. For cashew tress the irrigation is given at $30 \%$ of flowering and after completion of $50 \%$ harvest stops giving irrigation.

Climatic conditions suitable for growing cashew nuts are under temperatures ranges between 20 to $30^{\circ} \mathrm{C}$ with annual precipitation of 1000-1200 mm/year are ideal for cashew growing. In flowering and fruiting time, the temperature goes behind the $35^{\circ} \mathrm{C}$ which will affect the fruit setting and retention simultaneously in rainy season cashew crop will suffer from severe moisture stress conditions will affect the fruit setting and result in immature nuts and production will decrease.

In cashew production Andhra Pradesh holds second and Odisha holds third position under the area coverage of $17^{\circ} 49^{\prime} \mathrm{N}$ and $22^{\circ} 34^{\prime} \mathrm{N}$ latitude and $81^{\circ} \quad 27^{\prime} \mathrm{E}$ and $87^{\circ} 29^{\prime} \mathrm{E}$ longitude. State wise cashew production represented through Figure 1. The climatic conditions of Orissa covered with high temperature $\left(20-30^{\circ} \mathrm{C}\right)$, high humidity (80$90 \%$ ) medium to high rainfall (1200 -1500 $\mathrm{mm}$ ) and a mild winter rainfall.

Orissa major cashew growing areas are east and south eastern coastal plains, mid central, eastern ghat and in north central plateau. Cashew growing area covered 180.41 thousand ha and production capacity of 85.50 thousand MT. The main research station is located at Bhubaneswar under the OUAT. Though it is such an important fruit crop but every year it suffers with various biotic stresses such as anthracnose (Colletotrichum gloeosporides), pestalotia leaf spot (Pestalotia heterocornis), bacterial leaf and nut spot (Xanthomonas citri pv. anacardii) gummosis (Lasiodiplodia theobromine), the major pest is tea mosquito bug, leaf folder, leaf Webber, stem and root borer leaf minor etc. Die back of cashew and gummosis are two common diseases found in Orissa and more problematic disease is gummosis in Bhubaneswar region at Odisha.

In Andhra Pradesh the annual production of cashew is 46,913 ha of area with annual production of 12,500 tonnes of raw nuts. The raw cashew nut is the main commercial product of cashew tree. Processing of raw nuts and cashew nut shell is important for cashew processing. In Orissa annual profit of raw nuts generates 950 cores and processing raw nuts into kernels will get additional income of 250 cores, hence approximately will get up to 1200 cores. Annual production rate of Andhra Pradesh is shown under Table 1.

Biotic stresses are caused by living organisms like insects, bacteria, fungi which will affect the plant development and productivity. Dadili et al., in 2018 described major biotic stresses in case of cashew production. Major diseases are powdery mildew and gummosis in Andhra Pradesh and in Orissa die back and gummosis, anthracnose these are the diseasecausing damage to the cashew nut developing and automatically production will decrease. Cashew wilt caused by Fusaium oxysporum is another important disease, which affects cashew trees leading to yield losses of up to $100 \%$ if not properly controlled (Tibuhwa and Shomari, 2016).

\section{Major diseases found in cashew crop production}

Different kind of diseases acts as a major biotic stress. Among which anthracnose, 
powdery mildew, die back, leaf and nut blight are found to be more severe in cashew nut production in different regions of Andhra Pradesh which is represented through Figure 1 and Table 2.

\section{Anthracnose of cashew}

This fungal disease is Anacardium occidentale belong to the family Anacardiaceae. The disease will attack in vegetative parts and fruits and nuts, it not only affects the cashew but in other crops like mango, citrus, papaya

\section{Symptom}

Water-soaked lesions observed in leaves, inflorescence and nuts. Young apples develop later into orange brown or red lesions, infected shoots will appear like hanging nuts in next season also.

The disease during the flowering and fruiting period conditions is more favourable for these disease and conditions like relative humidity of $85-90 \%$ and temperature between $22^{\circ} \mathrm{C}$ $28^{\circ} \mathrm{C}$.

\section{Management}

\section{Cultural methods}

Clearing of dead and disease shoots of cashew, remove infected leaves from the entire tree.

\section{Chemical methods}

Spray the plants with $0.5 \%$ Bordeaux mixture or Mancozeb 0.25\%, Dithane M-45 0.3\%

\section{Biological methods}

Use ants to control the sucking pest.

\section{Die back of cashew}

The fungal disease is caused by Corticium salmonicolor

\section{Symptom}

Affected branches showed white and pinkish growth on the bark. Withering of panicles and die back of small flower stalks the fungus penetrates into the deeper tissue and cause the death of the shoots from the tip downwards so it is called die back, first it start from tips and then spread to downward then it will turn the greenish shoots into the brown which result in loss of flowers, heavy infection will appear like fire damage the disease is found in every growing areas.

\section{Management}

\section{Cultural methods}

Deep summer ploughing before the cultivation of crop Pruning the affected branches and diseases branches

\section{Chemical methods}

Protect the cut surface with Bordeaux paste and spray Bordeaux mixture $1.0 \%$ twice a year.

\section{Biological methods}

Conserve the natural enemy's release of telecoms egg parasites.

\section{Powdery mildew of cashew}

The disease is caused by Oidium anacardii

\section{Symptoms}

Purplish brown patches on the upper surface of the leaves mostly in the veins, leaves may 
become malformed. White powdery growth on the infected leaves and fruits and inflorescence infected parts turn brown and drying out of flowers and tender fruits. The disease is more in favourable conditions like cold nights, warm dry time and the optimum temperature ranges from $25^{\circ} \mathrm{C}-27^{\circ} \mathrm{C}$ optimum at $26 \%$ and relative humidity is 80 $100 \%$ with optimum at $95 \%$.

Overlapping of branches, twigs under the crown without penetration of sunlight and less rainfall is also favourable for the powdery mildew disease.

\section{Management}

\section{Cultural methods}

Sanitation practices and removal of infected shoot removal of unproductive tress and should not be over crowded tress it is more favourable for diseases occurrence.

\section{Chemical methods}

Application of wettable sulphur which increases the yield, sulphur dust and wettable powder 250 grams per tree at 14 days interval is found to be effective.

Before flowering five to six sprays of sulphur dust can control the disease.

\section{Biological methods}

Biological control with Bacillus subtilis and bacterial control like Bacillus licheniformis can control the disease. Use ants for sucking pest.

\section{Cashew leaf and nut blight}

Casual organism of the disease is Cryptosporiopsis sp. The disease has been reported is found to be severe during humid weather especially during off season rains, where severe infections affect the young flushing material (Sijaona et al., 2006).

\section{Symptoms}

Leaf and nut blight occur mainly on younger shoots and nuts leaves become silvery and with dark reddish-brown margins which enlarge and later form the defoliation. Infected younger nuts turned to be black while mature nuts showed dark lesions.

With coming of favourable condition white spore masses of the fungus appears from the infected lesion (Menge, 2013 and Menge, 2014).

\section{Management}

\section{Cultural methods}

Removing, destroying and burning of infected leaves, branches and twigs to control the pathogen.

\section{Chemical methods}

Spray with potassium chloride $720 \mathrm{~g} / \mathrm{l}$ is found to be effective.

\section{Cashew Pestalotia leaf spot}

The disease is caused by a fungus known as Pestalotia heterogonies.

\section{Symptoms}

The fungus form angular to irregular lesions on the mature leaves, upper surface of leaf become reddish brown and in the lower surface of become pale gray to whitish, defoliation occurs when it became severe. The infected leaves show regular to irregular polyclonal lesions on the leaf it starts from tip of the leaf and slowly it goes downward the 
leaf with mass of conidia on both the upper and lower surface of leaf. The favourable conditions for disease development at optimum temperature between $26-28^{\circ} \mathrm{C}$ and optimum relative humidity ranges from 80 $100 \%$ it can be minimized by free running water and wind.

\section{Management}

\section{Cultural methods}

Clearing and burning of infected branches and leaves, proper sanitization

\section{Chemical methods}

Foliar spray of Mancozeb 58\%WP (1gm per 0.8 lit) is found to be effective.

\section{Damping off of cashew}

The disease is caused by many fungal organisms like Fusarium sp., Pythium sp., Phytophthora palmivora.

\section{Symptoms}

The disease mainly occurs in the nursery field which shows withering, circular water-soaked stripes on the root zone followed by rotting of roots and lodging of plants. Water logging occurs if the container raised or nursery raised young plants are not well drained.

\section{Management}

\section{Cultural methods}

Nursery raised or container raised young plants should be well drained to overcome the water logging conditions.

\section{Chemical methods}

Carbendazim 50\% WP (1gm/0.5 -1lit) and cymoxanil mancozeb $72 \%$ WP1gm/0.5-1/lit water.

\section{Major pest infestation found in cashew} cultivation

The major pests identified in India are more than 55 species. In that tea mosquito bug is major pest affecting in the cashew in Andhra Pradesh and some other pest like stem or root borer, leaf minor, leaf webber, coconut bugs. Nene et al., in 2016 described major destructive insect pests of cashew production in Tanzania. Major pest affecting in cashew and their control measures and symptoms, nature of damage is explained below in detail manner under this article. Systematic position of major insect pests, affected area and management practices are shown in Table 3 and Table 4.

\section{Tea mosquito bug}

Tea mosquito bug is the major sucking pest in cashew and its scientific name is Helopeltis antonii belong to the Miridae family.

\section{Morphology of tea mosquito bug}

Adult tea mosquito bug is in reddish brown colour with black head and it lays eggs in shoots which accurately identified for the presence of two filaments.

Adult's lays about 83 eggs in shoots characterized with pair of filaments with slightly curved body. Hatching of egg takes and 7-8 days and it complete its life cycle by 23-25 days and its nymph is about $14-17$ days period covers.

\section{Nature of damage}

Nymph and adult will suck the sap from the inflorescence and leaves and it shows angular lesions and leaves are deformed along with veins later which shows drop off. If the insect feeds on the tender shoots it shows green lesions by extracting gum. 


\section{Symptoms}

Brown sunken spots on the developing apples and nuts when the bug feeds it, which appear as fire burn. When the infection is severe and it will reduce the growth of the tree and flowering shoots, formation of black spots on the nuts.

\section{Management}

Proper pruning is done to penetrate the sunlight to the inside canopy, should not intercrop with the crops that are host for Helopeltis, use weaver ants and some of the insecticides like Monocrotophos 36 SL and sprat Endosulfan $35 \mathrm{EC}$ at flower initiation and in fruiting time.

\section{Stem and root borer}

Plocaederus ferrugineus, the sucking pest belongs to the family Lepidoptera is responsible for major damage in cashew crops.

\section{Morphology of stem and root borer}

Adults are dark brown in colour they are in medium size measures about 25-35 mm long. In early stages they lay eggs on loose bark and in later stages on wood part.

Eggs are whitish in colour and takes hatching period 5-6 days followed grub period is about 6-7 months, pupal stage continued up to 65 days it takes one year to complete its life cycle.

\section{Nature of damage and symptoms}

The pest will affect the 15 years old plantation tress only. Wilting will appear when the pest feeds on the trunk and turned in grub stage. Finally, the tree will die within three years when leaves become yellow and twigs dry up.

\section{Management}

Uprooting of dead and infected trees from the orchard, use light traps to attract the pest present in the orchard, applying neem oil 5\% for trunk three times in a year, apply chlorpyriphos $0.2 \%$ / lit water by digging the ground near the affected plants, root feeding technique with Monocrotophos $10 \mathrm{ml}$ with water $10 \mathrm{ml}$, all this practices found to be effective.

\section{Leaf minor}

Causal pest: Acrocercops syngramma, belongs to the family lepidoptera.

\section{Morphology of leaf minor}

Leaf minor adults are silvery grey moth and caterpillars are in pale white in colour when it fully grown it looks like reddish brown. Moth lays eggs in the tender leaves its period is 2-3 days, larval period is 15 days and pupation take place in the soil and pupal period is $8-10$ days.

\section{Damage symptoms}

The larvae feed young leaves in the early stages and caterpillar in later stages which forming white blistered patches on the leaves. At later stages older leaves dry up and drooping off with big holes lesion.

\section{Management}

Cypermethrin is more effective in case of leaf minor infestation, spray $2.0 \mathrm{~kg} 50 \mathrm{WP}$ in 2000 lit/ha.

\section{Shoot and blossom Webber}

\section{Causal pest}

Macalla moncousalis 
Flushing period and flowering period is the favourable season for pest attack.

\section{Morphology of leaf and blossom Webber}

Female Webber is in green colour and lays 70 -90 eggs on the lower side of leaves. Hatching of egg takes 5-7 days and larval period is 1722 days followed by pupal period is $7-14$ days. Pupation takes place in the leaf folding's. Macalla completes its life cycle within 35 to 45 days.

\section{Damage symptoms}

The larva feeds on the tender leaves and inflorescence and web together. Scratched appearance on the apples and nuts found when it covered with web.

\section{Management}

Damaged plant parts are collected and destroyed. Spray Endosulfan 35EC in 2000 L of water.

India holds second ranking in global fruit production and supports international market through its wide import and export service. Maharashtra holds first position in cashew nut production followed by Andhra Pradesh and Orissa. In Andhra Pradesh so many rural people and farmers are depending on the cashew nut production which has more economic value in India.

Cashew is emerged as major foreign exchange after coffee. Government is providing subsidy for the cultivation of cashew nut. The cashew production of country accounts for $23.0 \%$ of the global production.

Large numbers of families are depending on cashew for their livelihood a greater number of families are working in the processing factories, millions of people involved directly or indirectly in cashew cultivation and processing and marketing.

Biotic stress related yield losses are considered to be one of the major problems in cashew production such as anthracnose (Colletotrichum gloeosporides), pestalotia leaf spot (Pestalotia heterocornis), bacterial leaf and nut spot (Xanthomonas citri pv. anacardii) gummosis (Lasiodiplodia theobromine), the major pest is tea mosquito bug, leaf folder, leaf webber, stem and root borer leaf minor etc.

The reasons of declined cashew production which point out by Ellias, 1980; Brown et al., 1984 were prolonged water stress, deteriorating soil fertility, pest and diseases etc.

Consortia of all kinds of management practices in terms of integrated disease management (IDM) are found to be the best solution to overcome this problem.

IDM is one of the potential tool kits to combat with diverse plant pathogens in a systematic way (Das and Pattanayak, 2020). Tough chemical management is very effective in some cases like - powdery mildew is best controlled by sulphur dust and wettable powder $2 \%$, but using of disease resistant and tolerant variety is found to be very ecofriendly and overwhelming approach.

Spraying of excessive or uncontrolled level of agrochemicals makes our soil and environment more toxic.

Recently Ministry of agriculture and farmers welfare, Govt. of India, notified through Govt. Gazette notification [S.O. 1512(E) dated 14th May, 2020] of list of prohibited insecticides which enlisted Acephate, Atrazine, Benfuracarb, Butachlor, Captan, Carbendazim, Carbofuran, Chloropyriphos, 
2,4 D, Deltamethrin, Dicofol, Dimethoate, Thiodicarb, Thiophanate methyl, Thiram, Dinocap, Diuron, Malathion, Mancozeb, Zineb, Ziram etc. So, marketing or business Methomyl, Monocrotophos, Oxyfluorfen, exposure or promotions of those Pendimethalin, Quinaphos, Sulfosulfuron, agrochemicals are restricted (Fig. 2).

Table.1 Area, production and productivity of cashew in Andhra Pradesh

\begin{tabular}{|l|c|c|c|}
\hline Year & Area (000 ha) & Production (000 MT) & $\begin{array}{c}\text { Productivity } \\
\text { (kg/ha) }\end{array}$ \\
\hline $\begin{array}{l}\mathbf{2 0 0 8} \\
\mathbf{0 9}\end{array}$ & 182 & 112 & 615 \\
\hline $\mathbf{2 0 0 9 - 1 0}$ & 182 & 99 & 544 \\
\hline $\mathbf{2 0 1 0 - 1 1}$ & 182 & 108 & 588 \\
\hline $\mathbf{2 0 1 1 - 1 2}$ & 183 & 110 & 607 \\
\hline $\mathbf{2 0 1 2 - 1 3}$ & 183 & 118 & 605 \\
\hline $\mathbf{2 0 1 3 - 1 4}$ & 184 & 100.8 & 648 \\
\hline $\mathbf{2 0 1 4 - 1 5}$ & 185 & 110 & 648 \\
\hline $\mathbf{2 0 1 5 - 1 6}$ & 186 & 97.8 & 539 \\
\hline $\mathbf{2 0 1 6 - 1 7}$ & 185.6 & 111.0 & 490 \\
\hline $\mathbf{2 0 1 7 - 1 8}$ & 185.5 & 96.9 & 600 \\
\hline $\mathbf{2 0 1 8 - 1 9}$ & 187.2 & 120.7 & 765 \\
\hline
\end{tabular}

Table.2 Disease attacking cashew crop in Andhra Pradesh

\begin{tabular}{|l|c|c|c|c|c|}
\hline $\begin{array}{l}\text { Cashew } \\
\text { diseases }\end{array}$ & Srikakulam & Vizianagaram & Vishakhapatnam & $\begin{array}{c}\text { East and } \\
\text { west } \\
\text { Godavari }\end{array}$ & $\begin{array}{c}\text { Coastal } \\
\text { zones }\end{array}$ \\
\hline Anthracnose & 42.1 & 24 & 12.7 & 34.6 & 17.3 \\
\hline $\begin{array}{l}\text { Powdery } \\
\text { mildew }\end{array}$ & 14.5 & 18.4 & 12.5 & 30.8 & 20.5 \\
\hline $\begin{array}{l}\text { Die back of } \\
\text { cashew }\end{array}$ & 27.0 & 14.5 & 8.9 & 12.6 & 6.9 \\
\hline $\begin{array}{l}\text { Leaf and nut } \\
\text { blight }\end{array}$ & 4.0 & 12.9 & 14.9 & 8.1 & 10.0 \\
\hline
\end{tabular}


Table.3 Systematic position of major insect pests of cashew and affected parts

\begin{tabular}{|l|l|l|l|l|}
\hline Common name & Scientific name & Family & Order & $\begin{array}{l}\text { Affected parts } \\
\text { of cashew }\end{array}$ \\
\hline Tea mosquito bug & $\begin{array}{l}\text { Helopeltis } \\
\text { antonii }\end{array}$ & Miridae & Hemiptera & Leaves, flowers \\
\hline Stem and root borer & $\begin{array}{l}\text { Plocaederus } \\
\text { ferrugineus }\end{array}$ & Cerambycidae & Coleoptera & $\begin{array}{l}\text { Stems and } \\
\text { roots }\end{array}$ \\
\hline Leaf minor & $\begin{array}{l}\text { Acrocercops } \\
\text { syngramma }\end{array}$ & Gracillariidae & Lepidoptera & Leaves \\
\hline $\begin{array}{l}\text { Shoot and blossom } \\
\text { Webbers }\end{array}$ & $\begin{array}{l}\text { Moncousalis } \\
\text { monaustidae }\end{array}$ & Lepidoptera & $\begin{array}{l}\text { Nuts, apples, } \\
\text { tender leaves } \\
\text { and } \\
\text { inflorescence }\end{array}$ \\
\hline
\end{tabular}

Table.4 Management practices for controlling major insect pests in cashew

\begin{tabular}{|c|c|c|c|}
\hline Pest in cashew & Cultural & Chemical & Biological \\
\hline Tea mosquito bug & $\begin{array}{l}\text { Damage symptoms } \\
\text { should be monitored } \\
\text { regularly, to penetrate } \\
\text { sunlight to the canopy } \\
\text { proper pruning is to be } \\
\text { done, the crops which } \\
\text { are host to cashew that } \\
\text { are not intercropped }\end{array}$ & $\begin{array}{c}\text { To flush new } \\
\text { formation } \\
\text { Monocrotophos } 36 \mathrm{~S} \\
\text { Lis applied, } \\
\text { imidacloprid } 0.6 \mathrm{ml} / \mathrm{lit}\end{array}$ & $\begin{array}{l}\text { Release Some of the } \\
\text { parasites like } \\
\text { Telenomus cuspis } \\
\text { (platygasteridae), } \\
\text { erythmeles } \\
\text { helopeltidid } \\
\text { (mymaridae) }\end{array}$ \\
\hline Stem and root borer & $\begin{array}{l}\text { Planting the cashew } \\
\text { grafts deeply and } \\
\text { removal of unwanted } \\
\text { and unproductive tress } \\
\text { because it acts as } \\
\text { inoculum for next } \\
\text { seasons, removal of } \\
\text { grubs, pupae and eggs } \\
\text { and inter ploughing }\end{array}$ & $\begin{array}{l}\text { Root feeding with } \\
\text { Monocrotophos } \\
10 \mathrm{ml} / 10 \mathrm{ml} \text { water for } \\
\text { twice a year, wounded } \\
\text { portion should be } \\
\text { cleaned with } \\
\text { chlorpyriphos } 0.2 \% \text {, } \\
10 \mathrm{ml} / \text { lit }\end{array}$ & $\begin{array}{l}\text { The exposed portion of } \\
\text { the roots and trunk } \\
\text { should not be injured, } \\
\text { to prevent egg laying } \\
\text { the infected part } \\
\text { should be cleaned with } \\
\text { kerosene }\end{array}$ \\
\hline Leaf minor & $\begin{array}{l}\text { Removal of infected } \\
\text { parts from the plants }\end{array}$ & $\begin{array}{l}\text { Spraying with } \\
\text { Monocrotophos } \\
1.5 \mathrm{ml} / \text { lit will } \\
\text { effectively manage } \\
\text { leaf minor }\end{array}$ & $\begin{array}{l}\text { Chelonus spp and } \\
\text { Sympiesis spp are } \\
\text { released to control the } \\
\text { leaf minor }\end{array}$ \\
\hline $\begin{array}{l}\text { Shoot and blossom } \\
\text { webber }\end{array}$ & $\begin{array}{l}\text { Proper pruning should } \\
\text { be done }\end{array}$ & $\begin{array}{l}\text { Spraying } \\
\text { Monocrotophos } \\
0.6 \mathrm{ml} / \text { lit when it is in } \\
\text { severe conditions }\end{array}$ & $\begin{array}{l}\text { Larva's are parasitized } \\
\text { by Apenteles Euproctis } \\
\text { Iphagus }\end{array}$ \\
\hline
\end{tabular}




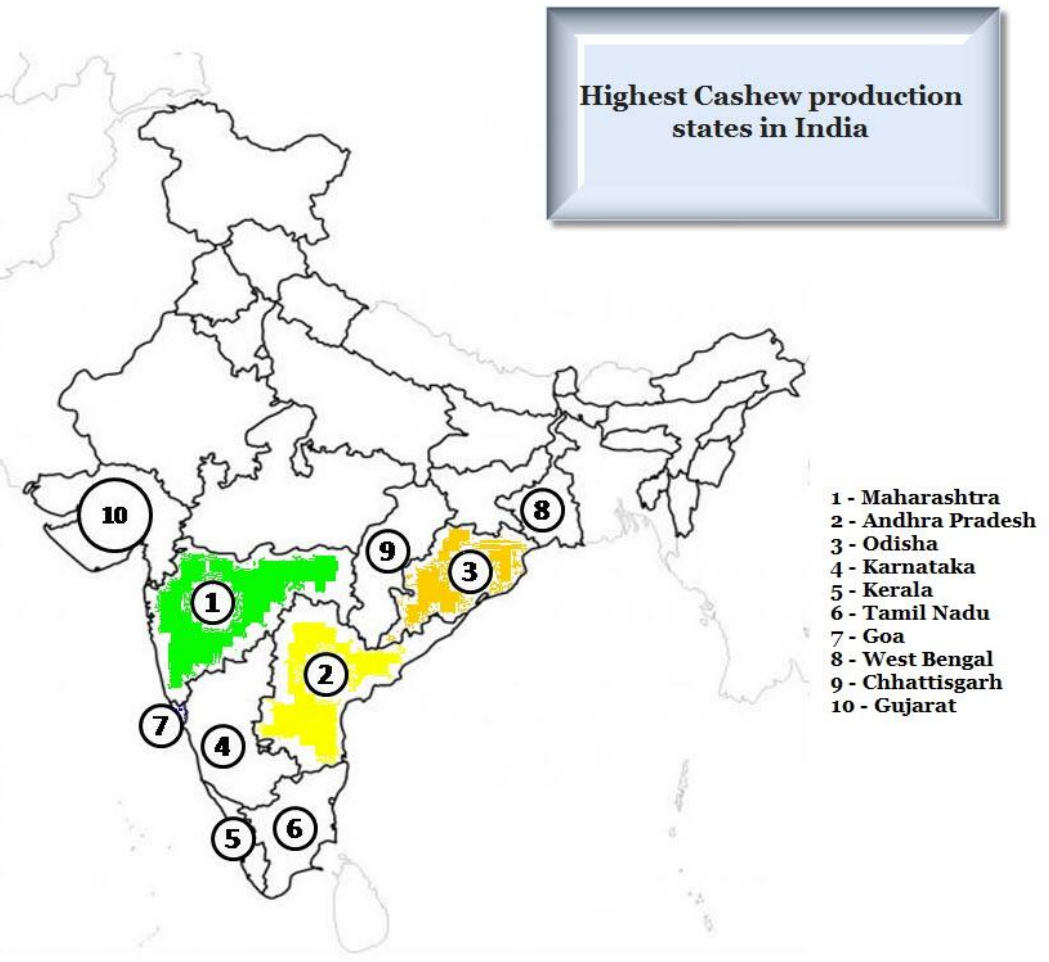

Figure.1 State wise cashew production in India



Figure.2 Graphical representation percent disease incidence per district basis in Andhra Pradesh

Government takes various initiative in terms of various acts and policies; skill develop hands on training courses through national horticultural mission which helps all classes of farming communities. Sometimes excessive use of hazardous agrochemicals turned the pathogenic nature and makes more virulent and aggressive through consecutive mutation. 
In another way, due to change in climatic condition pathogen autogenously mutated (Das et al., 2017). Therefore, screening and revision of those acts and policies makes the IDM every time more perfect. India is an agriculture-based country and economy stands on agricultural system. To safe guard our economy its moral, ethical responsibility to maintain IDM principles and strategies properly.

\section{References}

Brown L.C., Minja E. And Hamad A.S., 1984. Cashew production in east Africa. Paper presented at CABI'S first scientific conference on - Advancing agricultural production in Africa, Arusha, Tanzania, 12-18th February.

Das S., Dutta S., Ray S.R., 2017. First report of twig blight of ban tulsi (Croton bonplandianus Bail.) caused by Choanephora cucurbitarum (Berk \& Ravenel) Thaxt. In India. Journal of Plant Protection Research. 57(4): 441446.

Das S. and Pattanayak S., 2020. Integrated disease management on grapes- A pioneer of a reformed movement towards sustainability In. J. Curr. Microbiol. App. Sci. 9(5): 993-1005.

Dadili J.M., Peter A.M. and Ernest R.M., 2018. Status and Management of cashew disease in Tanzania. International Journal of Environment, Agriculture and Biotechnology. 3(5): 1590-1597.
Ellis F. 1980. A preliminary analysis of the decline in cashew nut production, 19741979: causes possible remedies and lesions for, rural development policy. Economic Research Bureau, University of Das es Salaam.

Menge D., Martha M., Bonaventure A., Shamte S. And Andreas, T. 2013. Effect of environmental conditions on the growth of Cryptosporiopsis spp. Causing leaf and nut blight on cashew (Anacardium occidentale L.). Journal of yeast and fungal research. 4(2): 12-20.

Menge D., Martha M., Bonaventure A., Shamte S. And Andreas T. 2014. Biology and infection mechanism of Cryptosporiopsis spp. Fungus causing blight disease on cashew. Journal of Plant Sciences. 2(6): 266-275.

Nene W.A., Makale A.R. and William M. 2016. Assessment of awareness on cashew insect pests, disease and management practices in Tanga region, Tanzania. 6(11): 1819-1824.

Sijaona M.E.R., Reeder R.H. and Waller J.M. 2006. Cashew leaf and nut blight - A new disease of cashew (Anacardium occidentale L.) in Tanzania caused by Cryptosporiosis sp.

http://www.bsapp.org.uk/ndr/jan2006/2 005-75.asp

Tibuhwa D.D. and Shomari S.H. 2016. Fusarium wilt disease: An emerging threat to cashew nut crop production in Tanzania. Asian Journal of Plant Pathology. 10: 36-48.

\section{How to cite this article:}

Sudeepta Pattanayak, Siddhartha Das and Hari Keerthi. 2020. Biotic Stress Related Challenges on Cashew Production in Andhra Pradesh, India. Int.J.Curr.Microbiol.App.Sci. 9(06): 38753885. doi: https://doi.org/10.20546/ijcmas.2020.906.457 